Commentary

\title{
Coronavirus in Spain: Fear of 'Official' Fake News Boosts WhatsApp and Alternative Sources
}

\author{
Carlos Elías * and Daniel Catalan-Matamoros \\ Department of Communication Studies, Carlos III University of Madrid, 28903 Madrid, Spain; \\ E-Mails: celias@hum.uc3m.es (C.E.), dacatala@hum.uc3m.es (D.C.-M.) \\ * Corresponding author
}

Submitted: 30 April 2020 | Accepted: 14 May 2020 | Published: 26 June 2020

\begin{abstract}
The communication of the Coronavirus crisis in Spain has two unexpected components: the rise of the information on social networks, especially WhatsApp, and the consolidation of TV programs on mystery and esotericism. Both have emerged to "tell the truth" in opposition to official sources and public media. For a country with a long history of treating science and the media as properties of the state, this very radical development has surprised communication scholars.
\end{abstract}

\section{Keywords}

Coronavirus; Covid-19; fake news; journalism; social media; Spain; WhatsApp; YouTube

\section{Issue}

This commentary is part of the issue "Health and Science Controversies in the Digital World: News, Mis/Disinformation and Public Engagement" edited by An Nguyen (Bournemouth University, UK) and Daniel Catalan (University Carlos III of Madrid, Spain).

(C) 2020 by the authors; licensee Cogitatio (Lisbon, Portugal). This article is licensed under a Creative Commons Attribution 4.0 International License (CC BY).

\section{Background}

Spain is a Western European country, but with some differences from others when it comes to scientific culture and scientific information in the media. In 17th and 18th centuries, the country suffered an oppressive inquisition which, after Galileo's trial, considered science a threat to religion and the State (Elías, 2019; Jacob, 1988). Furthermore, during the last century (1936-1975), the country suffered a dictatorship that considered science not as knowledge, but as a method of persuasion at the service of the state and religion. This perspective is still prevalent now amidst the Coronavirus crisis.

\section{Government Control of Coronavirus Communication}

In Spain, the heads of scientific organizations such as the Spanish National Research Council (CSIC) are chosen by the government. The royal academies of science and medicine are financed by the Government (Rubio, 2019); therefore, contrary to developments in Germany, the US and the UK, they fear a confrontation with power. The same applies to the state-run news agencies-e.g., the EFE Agency-and state-owned radio and television. In a way, they work just like the Chinese news agency Xinhua, i.e., they are propaganda by nature (Ingram, 2019; Twitter, 2019). This subsidized ecosystem of science and the media facilitates an environment in which an important part of public opinion does not believe in official sources-the government, government scientists, public media or royal academies-because they are not free to disagree with the official line. If there is no criticism, the impression is that information is either manipulated or controlled by the State.

One important aspect of government efforts to tame public opinion around Coronavirus is its misuse of language, namely the presentation of a negative reality through positive metaphors. For example, the lockdown is called "hibernation" of the economy. The centres to host thousands of asymptomatic patients were called "Noah's arks." The most successful of all is that the number of deceased and infected has become the "curve." 
The most repeated aim by the government and its scientists is not to reduce deaths or infections, but "to flatten the curve." Even anti-government journalists have fallen into the dialectical trap of these metaphors.

Another very controversial metaphor has been the "committee of wise experts," scientists hand-picked by the government. It does not call them "scientists" but "wise experts"; that is to say, "unquestionable." The newspaper El Mundo (second in national circulation) ran a headline on its front cover on April 12: 'The eight "wise experts" of the president against Coronavirus: Three of them were deniers at the beginning of the pandemic' (Rego \& Iglesias, 2020). The article, widely shared and discussed on social media, showed the ties of these experts with political parties, which might indicate hidden influences. Such dynamics are in fact used as a common government manoeuvre to control health information in the media (Catalan-Matamoros, 2011) and have been followed in other previous scientifically-based Spanish catastrophes such as the toxic spill of Doñana Natural Park in 1998, and the Prestige oil tanker accident in 2002. Here the government uses scientists with alignment to the dominant political ideology, who are used to cloak political slogans with science. The rest of government scientists do not have permission to speak with journalists under the threat of revealing state secrets, a very serious crime in Spain (Elías, 2007). The strategy is always the same: (1) electing a government scientist as a spokesperson who will then be rewarded with a promotion; (2) inundating journalists with tons of confusing data so that they do not have time to look for independent sources and check it; (3) threatening independent scientists (with indirect threats if they speak to the media); and, finally, (4) twisting language.

The Covid-19 crisis has also seen a novel element: the frequent and long press conferences given by the President, Pedro Sánchez (PSOE, centre-left wing party). But journalists could not attend these conferences to ask questions, prompting the Spanish Journalists' Association to complain. The government, in an attempt to give an image of transparency, invited journalists to a WhatsApp group to submit questions. The problem arose when the selection of these questions was made by the State Secretary for Communication, a position appointed by the President, and many journalists never saw their questions being asked at press conferences. Some media outlets and opposition politicians suggested that the government emulates the strategy of communist leaders, such as the Cuban Fidel Castro or Venezuelans Hugo Chávez and Nicolás Maduro with his Aló Presidente (Hello President). The alleged links with Venezuela of leaders of the Podemos political party, who acted as advisers to Chávez and Maduro, have inflamed social media, which criticise Podemos for adopting the Chávez communication strategy. But the President, Pedro Sánchez, a member of the PSOE, still needs Podemos to govern in coalition. This debate on whether Pedro Sánchez is emulating communist leaders has diverted the attention from the pandemic information given by the President. Many journalists refer to "yesterday's press conference" not as such but as "yesterday's Aló Presidente," undermining the President's image (Rodríguez, 2020).

Even the left-wing media such as Público have criticized the government for using the bandwagon effect (herd effect), whereby people assimilate the beliefs of the majority even when they are not convinced. In one article, Sánchez is criticised for copying the strategy of former US President Harry Truman: 'If you cannot convince them, confuse them' (Calderón, 2020). The journalist who wrote this comment, César Calderón, was immediately fired by Público (Carvajal, 2020), who admitted that it was pressured by the government, demonstrating how it exerts enormous power not only on state-run but also on private media. All this explains why that a large segment of the Spanish population prefers alternative sources-namely social media platforms and, quite curiously, "alternative television" shows that usually rely on mystery-for news during the Coronavirus crisis.

\section{Alternative Media Spaces for Independent Science}

In Spain there are two well-defined types of scientists. Those working at universities are quite independent and are allowed to publish their articles an in their blogs with full freedom. Indeed, some of them are being very closely followed during this Coronavirus crisis, such as members of the Spanish Mathematics Committee (Comité Español de Matemáticas, 2020). These scientists working at universities must pass a rigid and demanding national accreditation system to secure tenure and be promoted (ANECA, according to the Spanish acronym). On the other hand are scientists working in public research organizations such as the CSIC or the Carlos III National Health Institute. These do not have to pass any national accreditation or have to teach, although they are required to achieve the same research levels as university scientists. This privilege comes at a high price: They are not allowed to publish/speak without the approval of managers who are appointed by the government in office. If politicians tell the public to follow a specific expert advice which then turns out to be problematic, the blame is placed on scientists who cannot protest because this would be considered a serious disciplinary offense to reveal national secrets, even if they are scientific data. In Spain, it would be impossible for a government scientist to discredit the government, as, for example, Dr. Fauci is doing with US President Donald Trump (Mars, 2020). It is happening now when the left is in government, and it has happened before when the right was in office. Spain can thus be regarded as what the Portuguese sociologist Boaventura de Sousa Santos describes as 'politically democratic, but socially fascist societies' (Revista IHU, 2016).

This has led to quite a significant situation in the Coronavirus crisis: Pubic trust is placed in the information that comes through social media, especially 
WhatsApp, as well as through "alternative" television programs that usually cover mystery and esoterism. The first WhatsApp messages on the Coronavirus, which contradicted the official messages claiming that this pandemic was not dangerous, were videos and audios from clinicians denouncing the real situation they were facing in their own hospitals and asking for more protective equipment. Some of them were subjected to disciplinary action by their professional associations (La Voz, 2020; Vizoso, 2020), which restricted their freedom of expression against politicians and the authorities. Despite these threats, "alternative" TV programs, of an esoteric and mysterious nature (e.g., Fourth Millennium), invited these clinicians to speak (Molina, 2020). In this Coronavirus crisis, the digital media platform that has benefited most has been WhatsApp, which takes a leading role in positioning Spain as the country with the highest growth: $76 \%$ compared to $50 \%$ in other countries (EuropaPress, 2020). In April 2020, the company limited a number of groups to share messages, which was criticized by the media because only the messages against the government were restricted. WhatsApp quickly clarified that the orientation of the messages was not filtered, and that it was just a method to stop massive sharing of fake news. However, there was a general feeling that most of the forwarded messages were against the government.

Another winner seems to be YouTube. The Spanish state-run media are bound to the State, similarly to Chinese public media. In February, a report from Italy by the popular correspondent in the Spanish public television, Lorenzo Milá, went viral (TRESB, 2020): 'Covid-19 is a new type of flu; it is true, we have no viral memory, nor do we currently have a vaccine, but it is just a type of flu,' he declared. This report was shared widely on social networks and was retweeted by, among others, Pablo Echenique, the CSIC scientist and national deputy of Podemos (a political party governing in coalition together with the PSOE). The counterpoint in these previews about the pandemic was, curiously, given by a TV program on mystery and esotericism, Cuarto Milenio (Fourth Millennium), which attracted the highest audience ratings of all programs broadcast by the private channel Cuatro (Ecoteuve, 2020). While the public media tried to soften the pandemic, this program interviewed a Spaniard living in China who predicted, together with some guest experts, what would happen later (Reinoso, 2020). This would have been shocking for Spanish staterun television, and it led social networks to contrast the two approaches, which has surely impacted on public opinion. This development would have been impossible before the digital era. Following the pandemic restrictions, channel Cuatro put Fourth Millennium on pause, as well as others, but curiously, it coincided with the government support of 15 million euros for private media as these were considered a public service during the pandemic. Criticisms were raised in social media: Was this support aiming to influence a favourable view for the government? As this controversial TV program was put on pause, the presenter opened a YouTube channel which within a few days reached more than 500,000 subscribers (Jiménez, 2020). His interviews and his live shows surpassed a million views in only a few days and are highly forwarded on social media, strongly impacting public opinion.

As Spanish public opinion continues not to trust official sources, WhatsApp messages and YouTube channels criticizing the government have become so relevant and prevalent that the government has considered using the Prosecutor's Office to censor this alternative discourse in the social media. And, as Donald Trump does, the Spanish government's strategy to handle critical views is to call them fake news (Elías, 2018). Whether such strategy succeeds is a matter for much more research.

\section{Acknowledgments}

This work was supported by the Jean Monnet Chair "EU, Disinformation \& Fake News" (Erasmus+ Programme of the EU) and the Ministry of Science, Innovation and Universities of the Government of Spain under grant with reference RTI2018-097709-B-I00.

\section{Conflict of Interests}

The authors declare no conflict of interests.

\section{References}

Calderón, C. (2020, April 13). Los trucos de Moncloa para sobrevivir a la pandemia [Moncloa's tricks for surviving the pandemic]. Público. Retrieved from https://blogs.publico.es/cesar-calderon/2020/04/

13/los-trucos-de-moncloa-para-sobrevivir-a-lapandemia

Carvajal, A. (2020, April 16). César Calderón ficha por "Vozpópuli" tras su abrupta salida de "Público" [César Calderón signs for "Vozpópuli" after his abrupt farewell to "Público"]. Vozpópuli. Retrieved from https://www.vozpopuli.com/medios/CesarCalderon-ficha-Vozpopuli-salida-Publico_0_ 1346565545.html

Catalan-Matamoros, D. (2011). Health contents in press: Hidden influences in health? Revista Española de Comunicacion en Salud, 2(1), 1-2.

Comité Español de Matemáticas. (2020). Acción matemática contra el Coronavirus [Mathematical action against Coronavirus]. Comité Español de Matemáticas. Retrieved from http://matematicas. uclm.es/cemat/covid19

Ecoteuve. (2020). Audiencias de programas [Program ratings]. Ecoteuve. Retrieved from https://ecoteuve. eleconomista.es/cadena/CUATRO/audienciasprogramas/2020-03-22

Elías, C. (2007). The use of scientific expertises for political PR. In M. W. Bauer \& M. Bucchi (Eds.), Journalism, 
science and society: Science communication between news and public relations (pp. 227-238). New York, NY: Routledge.

Elías, C. (2018, October 4). El Gobierno y las "fake news" [The government and the "fake news"]. El Mundo. Retrieved from https://www.elmundo.es/opinion/ 2018/10/04/5bb4ee8de2704e3b1c8b45cf.html

Elías, C. (2019). Science on the ropes: Decline of scientific culture in the era of fake news. Cham: Springer.

EuropaPress. (2020, March 27). España, el país donde más crece el uso de WhatsApp durante la pandemia de Coronavirus [Spain, the country where the use of WhatsApp is growing most during the Coronavirus pandemic]. Abc. Retrieved from https://www.abc.es/ tecnologia/moviles/aplicaciones/abci-increibleaumento-whatsapp-espana-durante-pandemiacoronavirus-202003271357_noticia.html

Ingram, M. (2019). Facebook and Twitter profit from Chinese propaganda. Columbia Journalism Review. Retrieved from www.cjr.org/the_media_today/ facebook-twitter-china.php

Jacob, M. C. (1988). The cultural meaning of the scientific revolution. Philadelphia, PA: Temple University Press.

Jiménez, I. (2020). Canal Iker Jiménez. YouTube. Retrieved from https://www.youtube.com/channel/ UCS5gWLAaKdiLQb0m_FGxCDg

La Voz. (2020, March 21). El colegio de médicos de Pontevedra va a sancionar a los facultativos que instan a desoír a las autoridades sanitarias [Pontevedra's medical association will sanction doctors who urge people to disregard the health authorities]. La Voz de Galicia. Retrieved from https://www.lavozdegalicia. es/noticia/sociedad/2020/03/21/colegio-medicospontevedra-va-sancionar-facultativos-instan-desoirautoridades-santarias/00031584787771166427308. htm

Mars, A. (2020, March 24). El Doctor Fauci y Míster Trump [Dr. Fauci and Mr. Trump]. El País. Retrieved from https://elpais.com/internacional/2020-03-24/ el-doctor-fauci-y-mister-trump.html

Molina, B. (2020, March 22). Iker Jiménez da voz al polémico médico Jesús Candel (Spiriman) [Iker Jiménez gives voice to controversial doctor Jesús Candel (Spiriman)]. El Confidencial. Retrieved from https://www.elconfidencial.com/television/ programas-tv/2020-03-22/iker-jimenez-jesuscandel-medico-spiriman-coronavirus_2510616

Rego, P., \& Iglesias, L. (2020, April 12). Los ocho "sabios" del presidente contra el Coronavirus: Tres de ellos fueron negacionistas al principio de la pandemia [The President's eight "wise men" against the Coronavirus: Three of them were deniers at the beginning of the pandemic]. El Mundo. Retrieved from https:// www.elmundo.es/cronica/2020/04/12/5e91c0b321 efa06e5f8b4578.html

Reinoso, D. (2020). Todo lo que "Cuarto Milenio" nos advirtió que sucedería con el Coronavirus [Everything "Fourth Millennium" warned us would happen with the Coronavirus]. Cuatro. Retrieved from https:// www.cuatro.com/cuarto-milenio/Coronaviruspandemia-advertencia-iker-jimenez_18_ 2918745027.html

Revista IHU. (2016). Entrevista con Boaventura De Sousa Santos [Interview with Boaventura De Sousa Santos]. Instituto Humanitas Unisinos. Retrieved from www.ihu.unisinos.br/161-noticias/noticias-espanol/ 561394-vivimos-en-sociedades-politicamentedemocraticas-pero-socialmente-fascistasentrevista-con-boaventura-de-sousa-santos

Rodríguez, J. (2020, April 4). La prensa se harta del "Aló presidente" de Sánchez y no se prestará al montaje [The press is fed up with Sanchez's "Hello President" and will not lend itself to the montage]. Esdiario. Retrieved from https://www.esdiario.com/ 734027273/La-prensa-se-harta-del-Alo-presidentede-Sanchez-y-no-se-prestara-al-montaje.html

Rubio, R. (2019). El Gobierno destina 4,9 millones al Instituto de España, reales academias y otras entidades académicas [Government assigns 4.9 million to the Instituto de España, royal academies and other academic institutions]. Europapress. Retrieved from www.europapress.es/ciencia/noticiagobierno-destina-49-millones-instituto-espanareales-academias-otras-entidades-academicas20190823153409.html

TRESB. (2020, February 27). Las redes aplauden a Lorenzo Milá por su explicación sobre el Coronavirus [Social networks acclaim Lorenzo Milá for his explanation of the Coronavirus]. El Mundo. Retrieved from https://www.elmundo.es/f5/descubre/2020/02/26/ 5e5631aafdddff2c788b45a6.html

Twitter. (2019). Updating our advertising policies on state media. Twitter. Retrieved from https://blog. twitter.com/en_us/topics/company/2019/ advertising_policies_on_state_media.html

Vizoso, S. (2020, March 24). El hospital de Vigo destituye a una jefa médica tras criticar la desprotección de los sanitarios [Vigo hospital dismisses chief medical officer after criticizing lack of protection]. El País. Retrieved from https://elpais.com/sociedad/ 2020-03-24/el-hospital-de-vigo-destituye-a-unajefa-medica-tras-criticar-la-desproteccion-de-lossanitarios.html?utm_source $=$ Twitter\&ssm $=$ TW CM\#Echobox=1585087528 


\section{About the Authors}

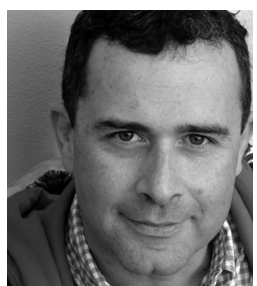

Carlos Elías (PhD) is a former Scientist and Journalist and now is Full Professor of Journalism at the Carlos III University of Madrid as well as the Jean Monnet Chair holder on the subject of the "EU, Disinformation and Fake News." His research focuses on the relationship between science and media. He has been a Visiting Scholar at the London School of Economics and at Harvard University. His latest book is Science on the Ropes (Springer, 2019).

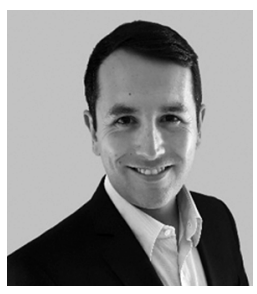

Daniel Catalan-Matamoros (PhD) is a Faculty at the Department of Communication Studies, Carlos III University of Madrid, and a Researcher of the Health Research Centre, University of Almeria. He has led public health and communication research projects supported by European funding schemes. He worked in a variety of national and international public health organizations such as the Health Ministry in Spain, the European Centre for Disease Prevention and Control, and the World Health Organization. 